\title{
URGENSI SENSUS LILIT BATANG SEJAK TBM 1 SEBAGAI STRATEGI MENINGKATKAN KERAGAAN DAN KESERAGAMAN TANAMAN KARET
}

\author{
Girth Census Since the $1^{\text {st }}$ Year of Immature Rubber to Increase Plant Homogenity
}

Akhmad Rouf, Setiono, dan Ari Santosa Pamungkas

Balai Penelitian Getas, J1. Patimura Km 6, Kotak Pos 804 Salatiga 50702, email: baligetas@yahoo.com

Diterima tgl 20 Februari 2013 / Disetujui tgl 22 Juli 2013

\begin{abstract}
Abstrak
Kecepatan tanaman karet memasuki matang sadap sangat dipengaruhi oleh tingkat pertumbuhan pada saat fase tanaman belum menghasilkan (TBM). Pengukuran lilit batang merupakan parameter yang sering digunakan dalam mengevaluasi pertumbuhan TBM. Pada umumnya pengukuran lilit batang pada saat TBM 1 sampai dengan TBM 3 dilakukan secara sampling, sedangkan pada TBM 4 dan 5 dilakukan secara sensus. Pengukuran lilit batang secara sampling seringkali kurang mencerminkan keadaan tanaman sebenarnya. Hal tersebut disebabkan ada subjektivitas dalam pengambilan sampel. Dampak yang sering terjadi adalah hasil evaluasi TBM $1-3$ dinilai memiliki lilit batang standar dan keragaan tanaman digolongkan baik bahkan superior. Setelah dilakukan sensus lilit batang pada TBM 4 dan 5, keragaan tanaman hasil penilaian kadang berbalik menjadi kurang baik dan persentase tanaman dengan lilit batang di bawah standar lebih banyak. Metode sensus sejak akhir TBM 1 dimaksudkan untuk mengidentifikasi setiap individu tanaman dan mengetahui kondisi tanaman secara lebih valid. Tanaman yang memiliki laju pertumbuhan kurang baik dapat segera diketahui dan dapat ditindaklanjuti melalui tindakan agronomis secara khusus dan selektif. Melalui tindakan tersebut, keragaan pada tanaman yang awalnya terhambat diharapkan menjadi lebih baik, sehingga persentase tanaman siap sadap semakin ditingkatkan dan waktu buka sadap tidak tertunda.
\end{abstract}

Kata kunci: karet, tanaman belum menghasilkan, lilit batang, sensus, keragaan tanaman, buka sadap.

\begin{abstract}
The maturity stage of rubber plant is greatly influenced by the growth performance during the immature period of the plant. So far stem girth measurement has become the most common method to evaluate the growth performance of rubber trees. Usually, stem girth is measured by sampling method during the first three years of immature period, and by census method for the fourth and fifth years of immature periods. The census method is more reliable than the sampling method. The weakness of the sampling method is subjectivity in selecting tree samples which results in inaccuracy of girth class determination i.e. more plants classified as standard an superior. Starting in the $4^{\text {th }}$ years of immature rubber plant, girth measurement uses census method and usually will have the opposite result than sampling method. Percentages of trees with inferior girth achievement are significantly higher than sampling method. To alleviate the weaknesses, census method should be used since the $1^{\text {st }}$ year of immature rubber plant. Trees classified as inferior can be identified early and special treatment can be applied immediately to accelerate girth growth. As a result, percentage of trees classified as standard and superior in the $5^{\text {th }}$ years of immature rubber plant can be increased and can be tapped timely.
\end{abstract}

Keywords: Hevea brasiliensis, immature rubber plant, girth, census, tapping time.

\section{Pendahuluan}

Laju pertumbuhan TBM akan berpengaruh terhadap potensi produksi tanaman pada saat disadap. Karena produktivitas dipengaruhi oleh jumlah tanaman disadap dan hari sadap, maka semakin banyak tanaman memenuhi kriteria matang sadap, semakin besar pula 
potensi produktivitasnya. Menurut Kuswanhadi dan Herlinawati (2012), kebun karet dianggap mencapai matang sadap jika $\geq$ $60 \%$ dari jumlah tanaman per ha telah mempunyai lilit batang $\geq 45 \mathrm{~cm}$. Persentase tersebut dapat diketahui melalui pengukuran lilit batang pada setiap individu tanaman karet atau disebut sensus lilit batang.

Selama ini sensus lilit batang dilakukan pada akhir TBM 4 atau menjelang TBM 5. Pengukuran lilit batang pada saat TBM 1 sampai dengan 3 dilakukan secara sampling. Metode sampling memiliki kelebihan antara lain mudah dan cepat, namun memiliki kelemahan yaitu data yang dihasilkan sering kali kurang valid dan kurang menggambarkan kondisi tanaman sebenarnya. Hal ini disebabkan subyektivitas petugas dalam pengambilan sampel lilit batang masih sangat besar. Dampaknya kebijakan yang akan diambil berupa perlakuan tindak lanjut tidak tepat. Padahal titik belok pertumbuhan tanaman karet terjadi pada umur 36 bulan (TBM 3), artinya perlakuan kultur teknis akan berpengaruh signifikan terhadap pertumbuhan sebelum TBM 3 .

Tulisan ini membahas urgensi pengukuran lilit batang secara sensus sejak TBM 1, guna mengetahui tingkat pertumbuhan tanaman sejak awal dan menentukan perlakuan selanjutnya. Melalui perlakuan-perlakuan khusus diharapkan sejak TBM 1 persentase tanaman baik (di atas standar) mencapai $\geq$ $60 \%$ dan meminimalisir adanya individu tanaman yang tertinggal pertumbuhannya, sehingga keragaan tanaman menjadi lebih baik dan seragam.

\section{Laju Pertumbuhan Tanaman}

Laju pertumbuhan tanaman adalah pertambahan atau perubahan volume sel tanaman per satuan waktu. Laju pertumbuhan merupakan suatu fungsi perubahan volume sel (W) selama selang waktu tertentu (t) dengan perubahan substrat pertumbuhan yang terdiri atas fotosintat dan unsur hara. Fungsi tersebut dapat dituliskan dalam persamaan sederhana sebagai berikut: $\mathrm{W}=\mathrm{f}(\mathrm{t})$. Pada umumnya volume sel menunjukkan pertambahan biomassa mengikuti bentuk $\mathrm{S}$ dengan waktu, yang dikenal dengan model sigmoid (Sitompul dan Guritno, 1995; Causton dan Venus, 1981; Hunt, 1982).

Model persamaan sederhana yang membentuk kurva sigmoid tersebut dapat diinterpretasikan menjadi model fungsi atau persamaan pertumbuhan terapan melalui beberapa asumsi. Sitompul dan Guritno (1995) menjelaskan bahwa ada beberapa model fungsi atau persamaan pertumbuhan yang grafiknya berbentuk kurva sigmoid, antara lain model Monomolekuler, Logistik, Gompertz, Richards, dan Chanter. Berikut ini penjelasan masing-masing model tersebut:

\section{a. Model Monomolekuler}

Da 1 a m model pertumbuhan Monomolekuler, laju transformasi substrat diasumsikan proporsional dengan konsentrasi subtrat. Dalam model ini, laju pertumbuhan nampak menurun secara terus-menerus dan tanpa titik belok (Tabel 1). Keadaan demikian tidak umum terjadi dalam pertumbuhan tanaman. Asumsi yang digunakan dalam model Monomolekuler juga tidak bisa mendekati keadaan sesungguhnya. Contoh asumsi tersebut adalah bahwa laju pertumbuhan tanaman diasumsikan tidak berubah (konstan). Padahal jaringan tanaman seperti jaringan fotosintesis, sel-sel di dalam jaringan meristematis, akar selalu mengalami proses perubahan dan tumbuh kembang seiring dengan bertambahnya waktu.

\section{b. Model Logistik}

Persamaan model Logistik berasal dari asumsi bahwa laju pertumbuhan tanaman dibatasi oleh kecepatan tumbuh spesifik, bobot kering dan jumlah subtrat yang tersedia. Pada model ini, kecepatan pertumbuhan semakin menurun sampai terhenti pada saat mencapai titik jenuh, misalnya keterbatasan makanan, substrat pertumbuhan, atau komponen lain yang menentukan pertumbuhan.
c. Model Gompertz
Berbeda dengan model Logistik, model Gompertz didasarkan pada asumsi bahwa 
substrat pertumbuhan tidak terbatas sehingga laju pertumbuhan selalu ditunjang oleh ketersediaan substrat pertumbuhan. Kecepatan tumbuh spesifik tidak selalu tetap, melainkan semakin menurun seiring umur tanaman mengikuti kinetik tingkat pertama yang menghasilkan persamaan eksponensial decay.

\section{d. Model Richards}

Pola pertumbuhan yang digambarkan oleh ketiga model sebelumnya dapat digambarkan oleh model Richards tetapi tergantung pada nilai parameter P. Model Richards akan sama dengan model Monomolekuler jika $\mathrm{P}=-1$, sama dengan model Logistik jika $P=1$, dan sama dengan model Gompertz jika $\mathrm{P}=0$.

\section{e. Model Chanter.}

Pola pertumbuhan pada model Chanter merupakan gabungan model Logistik dan Gompertz dengan parameter yang mempunyai pengertian sama. Parameter konstanta dalam persamaan Chanter adalah $\mathrm{W}_{0}$, , B, dan D. Kecepatan tumbuh spesifik $(\mu)$ ditentukan oleh 2 faktor, yaitu pengaruh linier subtrat pertumbuhan dan pengaruh waktu atau exp (-Dt) yang tergantung pada perjalanan waktu dan dapat diinterpretasikan sebagai diferensiasi, perkembangan dan senesens.

Persamaan Chanter sama (namun tidak identik) dengan persamaan Richards. Jika tanpa kemunduran kecepatan tumbuh spesifik (D 0), persamaan Chanter sama dengan persamaan logistis. Jika D mendekati /[n (Wa / $\mathrm{W}_{0}$ )] atau B (tidak ada batasan subtrat), persamaan menjadi sama dengan Gompertz. Turunan kedua persamaan Chanter $\left({ }_{2} \mathrm{~W} / \delta \mathrm{t}^{2}\right)$ ternyata tidak dapat diselesaikan secara analitik, sehingga umur titik belok juga tidak dapat dihitung (Tabel 1).

Tabel 1 menyajikan bentuk persamaan pada beberapa model fungsi pertumbuhan dan persamaan titik beloknya. Model persamaan Logistik, Gompertz dan Richards memiliki titik belok yang dipengaruhi oleh bobot kering dan kecepatan tumbuh tanaman. Titik belok pada model persamaan monomolekuler tidak dijumpai, sedangkan titik belok pada model Chanter tidak dapat dihitung.

Tabel 1. Bentuk persamaan model fungsi pertumbuhan dan titik beloknya

\begin{tabular}{|c|c|c|}
\hline $\begin{array}{l}\text { Model fungsi } \\
\text { pertumbuhan }\end{array}$ & Bentuk persamaan & Titik belok \\
\hline Model Monomolekuler & $\mathrm{W}=\mathrm{Wa}-\left(\mathrm{Wa}-\mathrm{W}_{0}\right) \mathrm{e}^{-\mathrm{kt}}$ & tidak ada \\
\hline Model Logistik & $\mathrm{W}=\frac{\mathrm{W}_{0} \mathrm{Wa}_{\mathrm{a}}}{\mathrm{W}_{0}+\left(\mathrm{Wa}_{\mathrm{a}}-\mathrm{W}_{0}\right) \mathrm{e}^{-\mu t}}$ & $\mathrm{t}^{*}=\frac{1}{\mu} \ln \left(\frac{\mathrm{W}_{\mathrm{a}}-\mathrm{W}_{0}}{\mathrm{~W}_{0}}\right)$ \\
\hline Model Gompertz & $\mathrm{W}=\mathrm{W}_{0} \exp \left[\mu_{0}\left(1-\mathrm{e}^{-\mathrm{Dt}}\right) / \mathrm{D}\right]$ & $\mathrm{t}^{*}=\frac{1}{\mathrm{D}} \ln \left(\frac{\mu_{0}}{\mathrm{D}}\right)$ \\
\hline Model Richards & $\mathrm{W}=\frac{\mathrm{W}_{0} \mathrm{Wa}}{\left[\mathrm{W}_{0}^{p}+\left(\mathrm{Wa}^{p}-\mathrm{W}_{0}^{p}\right) \mathrm{e}^{-\mathrm{kt}}\right]^{1 / p}}$ & $\mathrm{t}^{*}=\frac{1}{\mathrm{k}} \ln \left(\frac{\mathrm{Wa}^{p}-\mathrm{W}_{0} p}{p \mathrm{~W}_{0} p}\right)$ \\
\hline Model Chanter & $\mathrm{W}=\frac{\mathrm{W}_{0} \mathrm{~B}}{\mathrm{~W}_{0}+\left(\mathrm{B}-\mathrm{W}_{0}\right) \exp \left\{-\left[\mu\left(1-\mathrm{e}^{-\mathrm{Dt}}\right) / \mathrm{D}\right]\right\}}$ & tidak dapat dihitung \\
\hline \multicolumn{3}{|c|}{$\begin{aligned} \text { Keterangan: } & \mathrm{W}=\text { bobot kering } \\
\mathrm{W}_{0} & =\text { bobot kering awal } \\
\mathrm{Wa} & =\text { bobot kering akhir } \\
\exp & =\text { eksplonensial decay } \\
\mathrm{k} & =\text { total substrat yang tersedia }\end{aligned}$} \\
\hline
\end{tabular}


Selanjutnya Gambar 1 menunjukkan pencapaian umur titik belok yang sangat berbeda pada persamaan Logistik, Gompertz dan Richards. Tren persamaan Logistik terlihat merupakan bentuk kurva sigmoid yang paling halus likunya dibandingkan Gompertz dan Richards. Menurut Darmandono (1991) persamaan yang paling cocok untuk mewakili tren pertumbuhan tanaman karet adalah persamaan Richards, kemudian diikuti persamaan Gompertz. Antara kedua persamaan tersebut tidak berbeda nyata.

Laju petumbuhan pada TBM karet didasarkan pada pencapaian lilit batang setiap tahunnya. Vollema dan Dijkman (1939) cit Darmandono (1991) melaporkan bahwa laju perkembangan lilit batang tanaman karet juga berbentuk liku S (sigmoid). Tabel 2 memuat rekapitulasi data laju perkembangan lilit batang tanaman karet pada tiga hasil penelitian.

Pada Tabel 2 diketahui bahwa titik belok pertumbuhan lilit batang tanaman karet terjadi pada umur sekitar 36 bulan atau tahun ketiga. Setelah umur pada titik belok kecepatan pertumbuhan tanaman semakin lambat. Darmandono (1991) menyampaikan bahwa apapun yang diperlakukan dalam pemeliharaan tanaman pada saat mencapai titik belok tidak nyata berpengaruh terhadap keragaan tanaman. Periode titik belok juga berpengaruh terhadap potensi matang sadap tanaman karet. Semakin besar ukuran lilit batang pada saat mencapai titik belok, maka semakin besar pula lilit batang pada saat matang sadap.

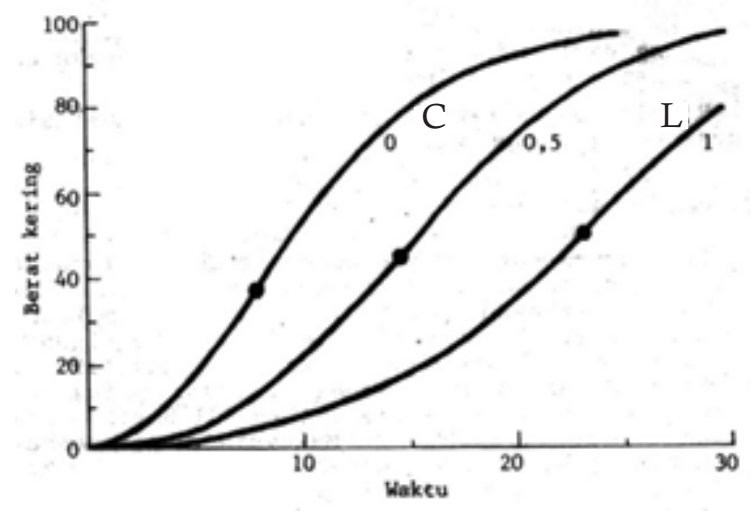

- Titik hitam pada grafik adalah titik belok

Gambar 1. Grafik fungsi pertumbuhan Richards dalam ukuran bebas. $\mathrm{W}_{0}=1, \mathrm{Wa}=100, \mathrm{k}=0,2$, $p \rightarrow 0$ (Gompertz), $p \rightarrow 1$ (Logistik) (France dan Thornley, 1984)

Tabel 2. Laju perkembangan lilit batang tanaman karet

\begin{tabular}{ccccccc}
\hline \multirow{2}{*}{$\begin{array}{c}\text { Umur } \\
\text { (bulan) }\end{array}$} & \multicolumn{2}{c}{ Penelitian 1 } & \multicolumn{2}{c}{ Penelitian 2 } & \multicolumn{2}{c}{ Penelitian 3 } \\
\cline { 2 - 7 } & $\begin{array}{c}\text { Lilit } \\
\text { batang } \\
(\mathrm{cm})\end{array}$ & $\begin{array}{c}\Delta \text { Lilit } \\
\text { batang } \\
(\mathrm{cm})\end{array}$ & $\begin{array}{c}\text { Lilit } \\
\text { Batang } \\
(\mathrm{cm})\end{array}$ & $\begin{array}{c}\Delta \text { Lilit } \\
\text { batang } \\
(\mathrm{cm})\end{array}$ & $\begin{array}{c}\text { Lilit } \\
\text { batang } \\
(\mathrm{cm})\end{array}$ & $\begin{array}{c}\Delta \text { Lilit } \\
\text { batang } \\
(\mathrm{cm})\end{array}$ \\
\hline 12 & 6,5 & 6,5 & 10,6 & 10,6 & 8,3 & $8,3^{*}$ \\
24 & 14,5 & 8,0 & 18,6 & 8,0 & 18,6 & 10,3 \\
36 & 25,5 & 11,0 & 27,7 & 9,1 & 30,9 & 12,3 \\
48 & 37,5 & 12,0 & 36,9 & 9,2 & 43,1 & 12,2 \\
60 & 48,5 & 11,0 & 45,6 & 8,7 & 53,1 & 10,0 \\
\hline Keterangan: Penelitian 1 & hasil penelitian Vollema dan Dijkman (1939) cit Darmandono (1991) \\
& Penelitian 2 = hasil penelitian Darmandono (1991) &
\end{tabular}


Berdasarkan analisis laju pertumbuhan tanaman dapat disimpulkan bahwa pada umur kurang dari 3 tahun merupakan periode terbaik bagi tanaman karet karena laju pertumbuhannya menunjukkan tren peningkatan. Pada periode tersebut perlakuan dalam rangka pemeliharaan atau perbaikan keragaan tanaman menjadi sangat penting.

\section{Evaluasi TBM Melalui Sensus Lilit Batang}

Lilit batang tanaman karet merupakan parameter penting dalam evaluasi pengelolaan TBM. Tabel 3 memuat rata-rata standar lilit batang tanaman karet pada umur 1-5 tahun.

Ukuran lilit batang juga merupakan parameter penentu buka sadap. Suatu kebun karet dianggap mencapai matang sadap jika $\geq$ $60 \%$ dari jumlah tanaman per ha telah mempunyai lilit batang $\geq 45 \mathrm{~cm}$ (Kuswanhadi dan Herlinawati, 2012). Ukuran $45 \mathrm{~cm}$ merupakan batas minimal atau standar lilit batang saat hendak disadap, sedangkan $60 \%$ merupakan persentase tanaman yang telah memiliki lilit batang di atas standar. Persentase tersebut biasanya diketahui pada akhir TBM 4 atau menjelang TBM 5, yaitu didasarkan hasil pengukuran lilit batang pada setiap individu tanaman karet atau disebut sensus lilit batang.

Permasalahan akan timbul apabila dari hasil sensus tersebut, ternyata persentase tanaman dengan ukuran lilit batang di atas standar $<60 \%$. Apabila kondisi tersebut terjadi pada TBM 4 atau 5, maka pelaksanaan buka sadap dapat dipastikan mundur. Tabel 4 menyajikan contoh hasil klasifikasi lilit batang secara sensus pada TBM 4 (kebun A - B) dan TBM 5 (kebun C-D).

Keragaan tanaman pada Kebun A dan D tergolong baik karena jumlah tanaman yang memiliki lilit batang standar dan superior telah mencapai $>60 \%$, sedangkan pada Kebun B dan $\mathrm{C}$ tergolong kurang baik karena banyak dijumpai tanaman inferior $(>40 \%)$. Dalam kondisi demikian, buka sadap pada Kebun B dan $\mathrm{C}$ tidak dapat dilakukan tepat waktu, sedangkan tindakan agronomis dalam rangka perbaikan keragaan tanaman dapat dikatakan sudah terlambat karena laju pertumbuhan lilit batang sudah mulai menurun.

Tabel 3. Standar lilit batang tanaman karet pada TBM

\begin{tabular}{cc}
\hline $\begin{array}{c}\text { Umur TBM } \\
\text { (tahun) }\end{array}$ & $\begin{array}{c}\text { Standar lilit batang } \\
(\mathrm{cm})\end{array}$ \\
\hline 1 & 8 \\
2 & 18 \\
3 & 30 \\
4 & 40 \\
5 & 48 \\
\hline
\end{tabular}

Tabel 4. Klasifikasi lilit batang pada TBM 4 dan 5

\begin{tabular}{|c|c|c|c|c|}
\hline \multirow{2}{*}{$\begin{array}{l}\text { Umur TBM dan } \\
\text { luas kebun }\end{array}$} & \multicolumn{3}{|c|}{$\begin{array}{l}\text { Persentase berdasarkan } \\
\text { klasifikasi lilit batang (\%) }\end{array}$} & \multirow{2}{*}{$\begin{array}{c}\text { Keterangan } \\
\text { (ukuran lilit batang) }\end{array}$} \\
\hline & Superior & Standar & Inferior & \\
\hline \multicolumn{5}{|l|}{ TBM 4} \\
\hline$\square$ Kebun A (91,41 ha) & 24,8 & 41,3 & 33,9 & Standar $=36,0-44,0 \mathrm{~cm}$ \\
\hline$\square$ Kebun B $(30,50$ ha) & 0,4 & 0,3 & 93,3 & $\begin{array}{l}\text { Inferior }<36,0 \mathrm{~cm} \\
\text { Superior }>44,0 \mathrm{~cm}\end{array}$ \\
\hline TBM 5 & & & & \\
\hline$\square$ Kebun C (98,05 ha) & 39,3 & 11,9 & 48,8 & Standar $43,2-52,8 \mathrm{~cm}$ \\
\hline$\square$ Kebun D (60,60 ha) & 35,9 & 32,5 & 31,6 & $\begin{array}{l}\text { Inferior }<43,2 \mathrm{~cm} \\
\text { Superior }>52,8 \mathrm{~cm}\end{array}$ \\
\hline
\end{tabular}

Sumber: Rekapitulasi data dari beberapa perkebunan karet 
Lain halnya apabila kondisi tanaman kurang baik (persentase inferior $>40 \%$ ) sudah diketahui sejak dini (akhir TBM 1), serangkaian tindakan kultur teknis dalam rangka perbaikan keragaan tanaman dapat berpengaruh signifikan karena laju pertumbuhan TBM 1 masih terus meningkat. Atas dasar itu, pengukuran lilit batang secara sensus sebaiknya dilakukan setiap akhir tahun dan dimulai sejak akhir TBM 1. Data hasil pengukuran sensus mencerminkan kondisi tanaman sebenarnya dan dapat dipertanggung jawabkan.

Pertimbangan lain sebagai penguat agar sensus lilit batang dilakukan sejak akhir TBM 1 adalah masih kuatnya sikap subyektif oleh petugas dalam pengambilan pohon sebagai sampel. Selama ini pengukuran lilit batang di perkebunan karet dilakukan secara sampling sejak akhir TBM 1 sampai dengan TBM 3, kemudian dilakukan secara sensus sejak akhir TBM 4 dan 5. Pengukuran secara sampling biasanya dilakukan melalui dua metode alternatif, yaitu secara acak sebanyak 10\% terhadap total populasi atau secara diagonal (sistem P-Q). Aplikasi metode tersebut sebenarnya cukup baik, mudah dan cepat. Hanya saja realisasi di lapangan, pengambilan pohon sampel cenderung bersifat subyektif. Sikap subyektif tersebut ditandai dengan kecenderungan untuk lebih memilih pohon yang memiliki keragaan baik sebagai sampel, sehingga sampel tidak mewakili secara keseluruhan dan data yang dihasilkan kurang akurat.

Menurut Sundiandi, et al. (2009), pengukuran lilit batang pada TBM karet dimaksudkan untuk:

a) menentukan kebijakan dan tindak lanjut perlakuan pengelolaan selanjutnya.

b) kontrol terhadap pertumbuhan dan homogenitas TBM dalam hubungannya dengan intensitas pemeliharaan dan pemupukan.

c) melengkapi data hasil analisis daun dalam penyusunan rekomendasi pemupukan TBM.

d) penentu saat dimulainya bukaan sadap baru (mutasi dari TBMke TM)
Manfaat lain yang akan diperoleh dari pengukuran lilit batang secara sensus, antara lain untuk mengetahui kondisi setiap indiviu tanaman, tingkat keragaan tanaman, persentase tanaman di atas standar, perkembangan populasi dan gambaran umum blok kebun.

Metode sensus lilit batang meliputi empat tahapan. Metode ini dirancang berdasarkan hasil observasi dan penyusunan rekomendasi dalam rangka pengawalan program investasi tanaman karet di beberapa perkebunan karet. Berikut ini disampaikan tahapan sensus lilit batang sekaligus contoh aplikasinya pada TBM 1.

a) Pembuatan blok kebun dan pemberian nomor pada tanaman

Penomoran pada tanaman dimaksudkan untuk mengidentifikasi setiap individu tanaman, sehingga dapat diketahui posisi tanaman tersebut dan tingkat pertumbuhannya. Adapun prinsip pembuatan blok kebun sama seperti pembuatan hanca disesuaikan dengan kondisi petakan dan peta kebun.

Obyek TBM 1 yang dijadikan contoh dalam tulisan ini berasal dari suatu kebun karet (Kebun E). Luas areal obyek tersebut 30,5 ha. Jumlah tanaman pada areal tersebut sebanyak 15.629 pohon (512 pohon/ha), dibagi menjadi 49 blok kebun.

Tahapan I sensus yaitu pemberian identitas blok kebun, biasanya dituliskan di bagian pojok petakan blok, misalnya blok kebun M.18. Adapun identitas/nomor tanaman dituliskan di batang tanaman pada ketinggian sekitar $150 \mathrm{~cm}$. Penomoran dapat dilakukan pada setiap individu tanaman, namun dalam prakteknya di lapangan, biasanya para pekebun menuliskan nomor pohon berdasarkan kelipatan setiap 5 atau 10 pohon. Contoh identitas blok dan nomor tanaman dimisalkan M.18-207, yang berarti menunjukkan tanaman nomor 207 pada blok M.18. 


\section{b) Pengukuran lilit batang secara sensus}

Setelah blok kebun dan penomoran pada tanaman selesai dibuat, selanjutnya dilakukan pengukuran lilit batang terhadap setiap individu tanaman atau disebut sensus lilit batang. Pengukuran lilit batang dilakukan pada ketinggian $100 \mathrm{~cm}$ dari pertautan okulasi.

c) Penentuan jumlah dan lebar kelas lilit batang

Menurut Paardekooper (1973), penghitungan lebar kelas didasarkan pada nilai simpangan baku (SD). Apabila lebar kelas sudah ditentukan, dengan sendirinya jumlah kelas akan tertentu pula. Sebagai contoh apabila lebar kelas ditentukan $=1,5 \times \mathrm{SD}$, maka jumlah kelas $=3$.

Jumlah kelas lilit batang pada TBM 1 Kebun E dikelompokkan menjadi 3 kelas, yaitu superior, standar dan inferior (Tabel 5). Pada Tabel 5 diketahui bahwa nilai $S D=2,2$; sehingga lebar kelas $=3,27$. Pada Tabel 5 juga diketahui bahwa rerata lilit batang adalah 7,9 $\mathrm{cm}$. Dengan demikian, tanaman kategori superior memiliki lilit batang > 9,6 cm; kategori standar memiliki lilit batang berkisar antara $6,3-9,6 \mathrm{~cm}$, sedangkan kategori inferior memiliki lilit batang $<6,3 \mathrm{~cm}$.

\section{d) Penerapan klasifikasi lilit batang}

Untuk mengetahui tingkat pengelolaan dan adaptabilitas tanaman terhadap perbedaan tingkat keserasian lahan pada TBM karet dapat dilakukan dengan klasifikasi (Setiono, 1990). Klasifikasi lilit batang juga dapat dimaksudkan untuk mengetahui tingkat keragaan tanaman.

Tabel 5 menyajikan data klasifikasi hasil sensus lilit batang pada seluruh blok TBM 1 di Kebun E. Berdasarkan nilai koefisien varian (CV) pada Tabel 5, diketahui bahwa tingkat homogenitas tanaman tergolong rendah (heterogen), yaitu memiliki nilai CV sebesar $27,5 \%$. Namun apabila dilihat dari persentase capaian lilit batang di atas standar, keragaan tanaman tergolong baik. Hal tersebut ditunjukkan dengan banyaknya tanaman yang telah memiliki lilit batang sesuai standar bahkan superior, yaitu mencapai $73,3 \%$. Persentase tanaman dalam kategori inferior hanya 26,7\%. Meskipun demikian, ternyata ada beberapa blok tanaman dan individu yang justru memiliki keragaan tanaman kurang optimal (inferior) dalam jumlah banyak. Kondisi tersebut dapat diketahui melalui proses pengkajian secara lebih detail terhadap data sensus lilit batang pada setiap blok dan setiap individu tanaman.

Tabel 5. Klasifikasi lilit batang pada TBM 1

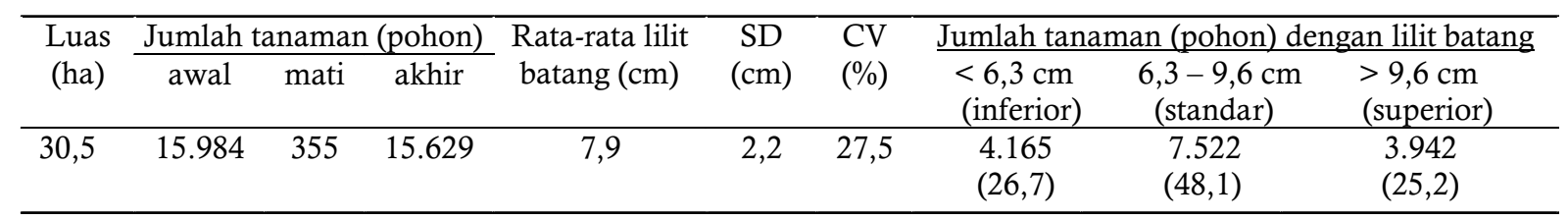

Keterangan: $\mathrm{SD}=$ standar deviasi, $\mathrm{CV}=$ koefisien varian

Angka dalam kurung adalah nilai \% dari jumlah tanaman 
Blok kategori inferior tersebut ditunjukkan pada Tabel 6, adapun individu yang terhambat pertumbuhannya ditunjukkan pada Gambar 2 . Pada Tabel 6 disampaikan beberapa blok yang tergolong inferior, salah satunya blok N.23. Pada blok N.23, jumlah tanaman yang masuk kategori inferior tergolong besar, yaitu 55,5\%, sedangkan yang masuk dalam kategori standar dan superior hanya $38,1 \%$, sisanya pohon mati sebesar $6,4 \%$. Pada blok kebun yang memiliki tanaman dalam kategori superior atau standar, upaya pemeliharaan dapat dipertahankan dan dilanjutkan secara normatif. Diupayakan agar persentase tersebut $(>60 \%)$ dapat dipertahankan hingga TBM 4 dan 5, sehingga tanaman tidak mundur sadap.

Tabel 6. Beberapa blok kebun kategori inferior

\begin{tabular}{|c|c|c|c|c|c|c|c|c|}
\hline \multirow[b]{2}{*}{$\begin{array}{l}\text { Nama } \\
\text { blok }\end{array}$} & \multirow[b]{2}{*}{$\begin{array}{l}\text { Rata-rata lilit } \\
\text { batang }(\mathrm{cm})\end{array}$} & \multirow[b]{2}{*}{$\begin{array}{l}\mathrm{SD} \\
(\mathrm{cm})\end{array}$} & \multirow[b]{2}{*}{$\begin{array}{l}\mathrm{CV} \\
(\%)\end{array}$} & \multicolumn{3}{|c|}{$\%$ tanaman dengan lilit batang } & \multirow{2}{*}{$\begin{array}{c}\% \\
\text { tanaman } \\
\text { mati }\end{array}$} & \multirow{2}{*}{$\begin{array}{c}\% \text { tanaman } \\
\text { standar dan } \\
\text { superior }\end{array}$} \\
\hline & & & & $\begin{array}{l}<6,3 \mathrm{~cm} \\
\text { (inferior) }\end{array}$ & $\begin{array}{c}6,3-9,6 \mathrm{~cm} \\
\text { (standar) }\end{array}$ & $\begin{array}{l}>9,6 \mathrm{~cm} \\
\text { (superior) }\end{array}$ & & \\
\hline M.21 & 6,0 & 1,0 & 16,0 & 64,6 & 28,3 & 0,2 & 6,9 & 28,5 \\
\hline M.25 & 4,9 & 1,0 & 20,1 & 84,2 & 6,5 & 0,0 & 9,3 & 6,5 \\
\hline N.22 & 6,4 & 1,2 & 19,4 & 52,0 & 45,4 & 0,5 & 2,1 & 45,9 \\
\hline N.23 & 6,2 & 1,4 & 22,4 & 55,5 & 36,4 & 1,7 & 6,4 & 38,1 \\
\hline N.24 & 5,4 & 1,1 & 20,7 & 72,1 & 18,8 & 0,0 & 9,1 & 18,8 \\
\hline N.25 & 5,1 & 1,2 & 23,6 & 84,1 & 13,0 & 0,0 & 2,9 & 13,0 \\
\hline 0.20 & 6,8 & 1,6 & 22,8 & 44,8 & 48,0 & 6,2 & 1,0 & 54,2 \\
\hline 0.21 & 5,9 & 1,0 & 17,9 & 67,8 & 25,7 & 0,1 & 6,4 & 25,8 \\
\hline P.21 & 6,3 & 1,1 & 18,1 & 57,8 & 37,5 & 1,1 & 3,6 & 38,6 \\
\hline Q.22 & 6,9 & 2,0 & 29,7 & 41,7 & 50,0 & 8,3 & 0,0 & 58,3 \\
\hline Q.24 & 5,7 & 1,4 & 23,8 & 63,9 & 33,8 & 0,3 & 2,0 & 34,1 \\
\hline R. 23 & 7,2 & 1,9 & 27,0 & 42,4 & 38,6 & 18,4 & 0,6 & 57,0 \\
\hline R.24 & 5,0 & 1,1 & 21,8 & 80,3 & 10,2 & 0,8 & 8,7 & 11,0 \\
\hline S. 24 & 6,6 & 1,7 & 25,0 & 45,6 & 45,6 & 5,3 & 3,5 & 50,9 \\
\hline
\end{tabular}

Idealnya, sejak TBM 1 tanaman memiliki rata-rata lilit batang sekitar $8 \mathrm{~cm}$ dan keragaan tanaman dalam kategori standar dan superior telah mencapai $>60 \%$. Persentase $60 \%$ tersebut didasarkan pada kriteria matang sadap kebun. Apabila sejak TBM 1 telah diketahui banyak tanaman yang tergolong kurang optimal (inferior), maka akan lebih mudah dalam menerapkan beberapa tindak agronomis guna memperbaiki keragaan tanaman. Hal itu dikarenakan laju pertumbuhan pada bentuk kurva sigmoid tanaman masih cukup tinggi dan belum menunjukkan titik belok (point of inflexion).

Manfaat praktis dari pengertian titik belok dalam kurva pertumbuhan bagi pengelolaan tanaman karet adalah bahwa seharusnya upaya-upaya perbaikan pertumbuhan ataupun pemeliharaan tanaman tidak boleh melewati umur titik belok tersebut. Hal itu dikarenakan setelah umur tersebut pertumbuhan menjadi semakin lambat sehingga perlakuan-perlakuan yang diberikan kurang memperoleh tanggapan tanaman (Darmandono, 1991). Pemupukan ekstra dapat dilakukan guna mendorong pertumbuhan tanaman, namun hanya berpengaruh signifikan pada tanaman karet berumur maksimal 3 tahun dan kondisinya tidak ternaung oleh tajuk tanaman di sebelahnya (Istianto dan Munthe, 2006). Penyulaman juga dapat dilakukan untuk menyeragamkan tanaman dengan jalan melakukan pembongkaran tanaman yang pertumbuhannya terhambat dan menggantinya dengan bibit sulaman (Nugroho, P. A., et al., 2007). Penyulaman pada TBM 1 dapat menggunakan bibit klonal berpayung dua. Penyulaman pada TBM 2 sebaiknya menggunakan bibit corestump, sedangkan pada TBM 3 sebaiknya sudah tidak dilakukan penyulaman karena tanaman sudah mulai ternaung oleh tanaman di sekitarnya. 
Berbagai tindakan tersebut dapat lebih fokus dilakukan hanya pada individu yang terhambat pertumbuhannya (inferior). Lokasi tanaman inferior dapat diketahui dari hasil klasifikasi lilit batang melalui pemberian warna (Gambar 2). Pada Gambar 2 diketahui bahwa individu tanaman terhambat ditandai warna merah, yaitu pada tanaman nomor 2,7 , 8, 19 ..... 365, 366, 367 dan 368. Proses pemberian warna dapat diolah menggunakan fasilitas di program microsoft excel pada menu conditional formatting.

\begin{tabular}{|c|c|c|c|c|c|c|c|c|c|c|c|c|c|c|c|c|c|c|c|c|c|c|c|}
\hline $\mathrm{NP}$ & LB & NP & LB & $\mathrm{NP}$ & LB & \begin{tabular}{|l|} 
NP \\
\end{tabular} & LB & $\mathrm{NP}$ & LB & $\mathrm{NP}$ & LB & NP & LB & $\mathrm{NP}$ & LB & NP & LB & NP & LB & NP & LB & \begin{tabular}{|l|} 
NP \\
\end{tabular} & LB \\
\hline 1 & 7 & 34 & 7 & 67 & 6 & \begin{tabular}{|l|}
100 \\
\end{tabular} & 6 & 133 & 8 & 166 & 6 & 199 & 6 & 232 & 6 & 265 & 5 & 298 & 8 & 331 & 6 & \begin{tabular}{|l|}
364 \\
\end{tabular} & 5 \\
\hline 2 & 6 & 35 & 8 & 68 & 6 & \begin{tabular}{|l|}
101 \\
\end{tabular} & 7 & 134 & 7 & 167 & 7 & 200 & 7 & 233 & 7 & 266 & 6 & 299 & $\mathrm{X}$ & 332 & 6 & \begin{tabular}{|l|}
365 \\
\end{tabular} & 4 \\
\hline 3 & 10 & 36 & 5 & 69 & 6 & \begin{tabular}{|l|}
102 \\
\end{tabular} & 6 & 135 & 7 & 168 & 5 & 201 & 6 & 234 & 6 & 267 & 6 & 300 & $\mathrm{X}$ & 333 & 4 & \begin{tabular}{|l|}
366 \\
\end{tabular} & 5 \\
\hline 4 & 7 & 37 & 7 & 70 & 7 & 103 & 10 & 136 & 8 & 169 & 7 & 202 & 6 & 235 & 7 & 268 & 8 & 301 & 4 & 334 & 5 & 367 & 5 \\
\hline 5 & 7 & 38 & 6 & 71 & 6 & 104 & 8 & 137 & 7 & 170 & 8 & 203 & 7 & 236 & 7 & 269 & $\mathrm{X}$ & 302 & 4 & 335 & 4 & 368 & - \\
\hline 6 & 7 & 39 & 9 & 72 & 7 & 105 & 7 & 138 & 7 & 171 & 8 & 204 & 5 & 237 & 6 & 270 & 6 & 303 & 5 & 336 & 5 & & \\
\hline 7 & 6 & 40 & 9 & 73 & 7 & \begin{tabular}{|l|}
106 \\
\end{tabular} & 7 & 139 & 7 & 172 & 7 & 205 & 8 & 238 & 6 & 271 & 5 & 304 & 6 & \begin{tabular}{|l|}
337 \\
\end{tabular} & 5 & & \\
\hline 8 & 6 & 41 & 8 & 74 & 6 & \begin{tabular}{|l|}
107 \\
\end{tabular} & 6 & 140 & 8 & 173 & 7 & 206 & 6 & 239 & 7 & 272 & 4 & 305 & $\mathrm{X}$ & 338 & 7 & & \\
\hline \begin{tabular}{l|l} 
& \\
\end{tabular} & 8 & 42 & 5 & 75 & 5 & 108 & 8 & 141 & 6 & 174 & 7 & 207 & 5 & 240 & 7 & 273 & 4 & 306 & $\mathrm{X}$ & 339 & 6 & & \\
\hline 10 & 8 & 43 & 7 & 76 & 7 & \begin{tabular}{|l|}
109 \\
\end{tabular} & 8 & 142 & 7 & 175 & 5 & 208 & 6 & 241 & 6 & 274 & $\mathrm{X}$ & 307 & 4 & \begin{tabular}{|l|}
340 \\
\end{tabular} & 5 & & \\
\hline 11 & 8 & 44 & 11 & 77 & 9 & 110 & 8 & 143 & 7 & 176 & 6 & 209 & 6 & 242 & 7 & 275 & $\mathrm{X}$ & 308 & 4 & 341 & 5 & & \\
\hline 12 & 8 & 45 & $\mathrm{X}$ & 78 & 7 & 111 & 8 & 144 & 6 & 177 & 5 & 210 & 7 & 243 & 8 & 276 & 6 & 309 & 4 & \begin{tabular}{|l|}
342 \\
\end{tabular} & 6 & & \\
\hline 13 & 7 & 46 & 9 & 79 & 6 & \begin{tabular}{|l|}
112 \\
\end{tabular} & 6 & 145 & 6 & 178 & 6 & 211 & 7 & 244 & 5 & 277 & 5 & 310 & 5 & \begin{tabular}{|l|}
343 \\
\end{tabular} & 5 & & \\
\hline 14 & 9 & 47 & $\mathrm{X}$ & 80 & 5 & 113 & 6 & 146 & 7 & 179 & 6 & 212 & 6 & 245 & 6 & 278 & 6 & 311 & 5 & 344 & $\mathrm{X}$ & & \\
\hline 15 & 7 & 48 & $\mathrm{X}$ & 81 & 4 & \begin{tabular}{|l|}
114 \\
\end{tabular} & 6 & \begin{tabular}{|l|}
147 \\
\end{tabular} & 9 & 180 & 5 & 213 & 8 & 246 & 7 & 279 & $\mathrm{X}$ & 312 & 6 & 345 & 5 & & \\
\hline 16 & $\mathrm{X}$ & 49 & 4 & 82 & 7 & 115 & 6 & 148 & 7 & 181 & 6 & 214 & 5 & 247 & 7 & 280 & $\mathrm{X}$ & 313 & 6 & \begin{tabular}{|l|}
346 \\
\end{tabular} & 5 & & \\
\hline 17 & 8 & 50 & 10 & 83 & $\mathrm{X}$ & 116 & 6 & 149 & 6 & 182 & 5 & 215 & 4 & 248 & 6 & 281 & 6 & 314 & 5 & \begin{tabular}{|l|}
347 \\
\end{tabular} & 6 & & \\
\hline 18 & 10 & 51 & 9 & 84 & 5 & \begin{tabular}{|l|}
117 \\
\end{tabular} & 5 & 150 & 6 & 183 & 4 & 216 & 5 & 249 & 4 & 282 & 6 & 315 & 6 & 348 & 5 & & \\
\hline 19 & 6 & 52 & 9 & 85 & 7 & 118 & 7 & 151 & 5 & 184 & 4 & 217 & 4 & 250 & 5 & 283 & 5 & 316 & 4 & \begin{tabular}{|l|}
349 \\
\end{tabular} & 6 & & \\
\hline 20 & 7 & 53 & 8 & 86 & 7 & \begin{tabular}{|l|}
119 \\
\end{tabular} & 7 & 152 & 4 & 185 & 4 & 218 & 4 & 251 & 5 & 284 & 8 & 317 & 4 & 350 & $\mathrm{X}$ & & \\
\hline 21 & 6 & 54 & 8 & 87 & 7 & \begin{tabular}{|l|l|}
120 \\
\end{tabular} & 7 & 153 & 5 & 186 & 6 & 219 & 6 & 252 & 6 & 285 & 5 & 318 & 6 & 351 & 4 & & \\
\hline 22 & 6 & 55 & 7 & 88 & 7 & 121 & 8 & 154 & 8 & 187 & 8 & 220 & 5 & 253 & 5 & 286 & 6 & 319 & 5 & 352 & 4 & & \\
\hline 23 & 5 & 56 & 8 & 89 & 5 & 122 & 7 & 155 & 6 & 188 & 6 & 221 & 5 & 254 & 6 & 287 & 6 & 320 & $\mathrm{X}$ & 353 & 4 & & \\
\hline 24 & 5 & 57 & 9 & 90 & 6 & \begin{tabular}{|l|}
123 \\
\end{tabular} & 6 & 156 & 5 & 189 & 5 & 222 & 6 & 255 & 5 & 288 & 5 & 321 & 6 & 354 & 5 & & \\
\hline 25 & 6 & 58 & 8 & 91 & $\mathrm{X}$ & 124 & 6 & 157 & 6 & 190 & 4 & 223 & 6 & 256 & 6 & 289 & 5 & 322 & 7 & 355 & 4 & & \\
\hline 26 & 7 & 59 & 8 & 92 & 5 & \begin{tabular}{|l|}
125 \\
\end{tabular} & 6 & 158 & 7 & 191 & 6 & 224 & 6 & 257 & 6 & 290 & 5 & 323 & 5 & 356 & 4 & & \\
\hline 27 & 8 & 60 & 8 & 93 & 6 & \begin{tabular}{|l|}
126 \\
\end{tabular} & 6 & 159 & 7 & 192 & 4 & 225 & 5 & 258 & 5 & 291 & 5 & 324 & 6 & \begin{tabular}{|l|}
357 \\
\end{tabular} & 5 & & \\
\hline 28 & 10 & 61 & 8 & 94 & 7 & \begin{tabular}{|l|}
127 \\
\end{tabular} & 7 & 160 & 5 & 193 & 4 & 226 & 5 & 259 & 5 & 292 & 7 & 325 & 6 & 358 & 7 & & \\
\hline 29 & 9 & 62 & 7 & 95 & 7 & \begin{tabular}{|l|l|}
128 \\
\end{tabular} & 7 & 161 & 7 & 194 & 4 & 227 & 6 & 260 & 5 & 293 & 5 & 326 & 5 & \begin{tabular}{|l|}
359 \\
\end{tabular} & 4 & & \\
\hline 30 & 8 & 63 & 9 & 96 & 5 & \begin{tabular}{|l|}
129 \\
\end{tabular} & 5 & 162 & 5 & 195 & 4 & 228 & 6 & 261 & 6 & 294 & 4 & 327 & $\mathrm{X}$ & 360 & 5 & & \\
\hline 31 & 7 & 64 & 6 & 97 & 5 & 130 & 6 & 163 & 8 & 196 & 4 & 229 & 7 & 262 & 5 & 295 & 7 & 328 & $\mathrm{X}$ & 361 & 5 & & \\
\hline 32 & 7 & 65 & 8 & 98 & 4 & \begin{tabular}{|l|}
131 \\
\end{tabular} & 8 & 164 & 7 & 197 & 9 & 230 & 6 & 263 & 5 & 296 & 6 & 329 & $\mathrm{X}$ & 362 & 5 & & \\
\hline $33 \mid$ & 8 & 66 & 9 & 99 & 7 & 132 & 6 & 165 & 6 & 198 & 6 & 231 & 8 & 264 & 6 & 297 & 5 & 330 & $\mathrm{X}$ & 363 & 5 & & \\
\hline
\end{tabular}

Keterangan: $\mathrm{NP}=$ nomor pohon, $\mathrm{LB}=$ ukuran lilit batang $(\mathrm{cm}), \mathrm{X}=$ pohon mati

$$
\text { = inferior } \quad \text { = standar } \quad \square=\text { superior }
$$

Gambar 2. Klasifikasi data lilit batang pada setiap nomor pohon di Blok N.23 


\section{Kesimpulan}

Laju pertumbuhan tanaman karet mengikuti persamaan kurva sigmoid. Titik belok pertumbuhan tanaman karet terjadi pada umur 36 bulan atau umur 3 tahun. Setelah tanaman mencapai umur tersebut laju pertumbuhannya semakin melambat. Setelah melewati titik belok, tindakan agronomis melalui perlakuan ekstra dalam rangka perbaikan tanaman tidak berpengaruh secara nyata.

Sensus lilit batang sejak akhir TBM 1 sangat penting dilakukan untuk mengoptimalkan pertumbuhan keragaan tanaman melalui serangkaian tindakan agronomis yang tepat berdasarkan kondisi setiap individu tanaman yang sebenarnya.

Melalui 4 tahapan dalam sensus lilit batang, dapat diketahui blok atau individu yang terhambat pertumbuhannya (inferior). Tindakan kultur teknis dalam rangka memperbaiki keragaan tanaman dapat lebih difokuskan pada blok atau individu tanaman yang tergolong inferior.

\section{Daftar Pustaka}

Aidi-Daslin, I. Suhendry, and R. Azwar. 2000. Growth characteristic and yield performance of recommended rubber clones in commercial plantings. Proc. Indonesian Rubb. Conf. and IRRDB Symp. Indonesia Rubber Research Institute. p: 150-158.

Causton, D. R. and J. C. Venus. 1981. Whole plant growth analysis. In: the biometry of plant growth. Edward Arnold, London.

Darmandono. 1991. Analisis pertumbuhan tanaman karet. Risalah Penelitian RC Getas, 17, p: 1 - 25.

France, J. and J. H. M. Thornley. 1984. Mathe matical models in agriculture: quantitative methods for the plant, animal and ecological sciences. British Library.
Hunt, R. 1982. Asymptotic functions. In: plant growth curve - the functional approach to plant growth analysis. Edward Arnold, London.

Istianto dan H. Munthe. 2006. Upaya meningkatkan keseragaman tanaman karet belum menghasilkan dengan pemupukan ekstra. Pros. Lok. Nas. Budidaya Tanaman Karet. Medan, 4-6 September 2006.

Kuswanhadi dan E. Herlinawati. 2012. Penyadapan. Dalam Saptabina Usahatani Karet Rakyat (Edisi keenam). Pusat Penelitian Karet, Balai Penelitian Sembawa, Palembang.

Nugroho, P. A., Istianto, dan Karyudi. 2007. Metode peningkatan keseragaman tanaman karet belum menghasilkan. Warta Perkaretan, 26 (2), p: 10-19.

Paardekooper, E. C. 1973. Manual of field experimentation in rubber. Part I, strengthening research on rubber and oil palm in North Sumatra. UNDP/FAO Project Ins/72/014

Permadi, P. dan E. Ginting. 2009. Evaluasi keragaan klon-klon karet di PT Socfin Indonesia. Pros. Lok. Nas. Pemuliaan Tanaman Karet. Hal : 110-117.

Setiono. 1990. Metode klasifikasi dan kriteria masak sadap tanaman karet. Risalah Penelitian R. C. Getas, 16, p: 49-62.

Sitompul, S. M. dan B. Guritno. 1995. Model pertumbuhan: analisis pertumbuhan tanaman. Gadjah Mada Unversity Press, Yogyakarta.

Sundiandi, J. H. Sihombing, N. Siagian, dan Karyudi. 2009. Upaya mempercepat masa tanaman belum menghasilkan tanaman karet di PTP Nusantara III. Pros. Lok. Nas. Pemuliaan Tanaman Karet. Hal : 123-140. 